\title{
Synthesis of $\mathrm{Li}_{2} \mathrm{Mn}_{3} \mathrm{O}_{7}$ and Application to Hybrid Capacitor
}

\author{
Hunuk Kim ${ }^{\mathrm{a}, \mathrm{b}}$, Kyoung Hee Shin ${ }^{\mathrm{b}}$, Bum-Suk Lee ${ }^{\mathrm{b}}$, Myung Seok Jeon ${ }^{\mathrm{b}}$, Kyu-Nam Jung ${ }^{\mathrm{b}}$, Yang-Kook Sun ${ }^{\mathrm{a}}$ \\ and Chang Soo Jin ${ }^{\mathrm{b}, \boldsymbol{t}}$ \\ ${ }^{a}$ Department of Chemical Engineering, Hanyang University, 17 Haengdang-dong, Seongdong-gu, Seoul 133-791, Korea \\ ${ }^{b}$ Korea Institute of Energy research, 71-2 Jang-Dong, Yuseong-gu, Daejeon 305-343, Korea
}

\begin{abstract}
:
In order to apply hybrid capacitor, $\mathrm{Li}_{2} \mathrm{Mn}_{3} \mathrm{O}_{7}$ was synthesized by combustion method using $\mathrm{LiNO}_{3}$, $\mathrm{Li}\left(\mathrm{CH}_{3} \mathrm{COO}\right) \cdot 2 \mathrm{H}_{2} \mathrm{O}$ and $\mathrm{Mn}\left(\mathrm{CH}_{3} \mathrm{COO}\right)_{2} \cdot 4 \mathrm{H}_{2} \mathrm{O}$. Spinel pattern was identified the samples calcined over $400^{\circ} \mathrm{C}$ in XRD. Intensity of $\mathrm{Mn}_{2} \mathrm{O}_{3}$ peak increased as the calcination temperature increased. To decide $\mathrm{n} / \mathrm{p}$ ratio and to investigate electrochemical properties, charge-discharge tests of $\mathrm{Li} /$ $\mathrm{Li}_{2} \mathrm{Mn}_{3} \mathrm{O}_{7}$ and $\mathrm{Li} / \mathrm{AC}$ half-cell were carried out. Applying to $\mathrm{AC} / \mathrm{Li}_{2} \mathrm{Mn}_{3} \mathrm{O}_{7}$ hybrid capacitor, it had high discharge capacitance of $32.8 \mathrm{~F} / \mathrm{cc}$ at $100 \mathrm{~mA} / \mathrm{g}$.
\end{abstract}

Keywords : $\mathrm{Li}_{2} \mathrm{Mn}_{3} \mathrm{O}_{7}$, Hybrid capacitor, Decomposition, Discharge capacitance

Received December 13, 2010 : Accepted December 28, 2010

\section{Introduction}

For the purpose of higher energy density, easier synthesis of electrode material, less toxic of starting material and lower price, many researchers has been studied hybrid capacitor using $\mathrm{Li}_{4} \mathrm{Mn}_{5} \mathrm{O}_{12}$ which reported high specific discharge capacitance, good electrochemical properties. ${ }^{1-5)} \mathrm{Li}_{4} \mathrm{Mn}_{5} \mathrm{O}_{12}$ and $\mathrm{Li}_{2} \mathrm{Mn}_{3} \mathrm{O}_{7}$ which are lithia-stabilized system have the same as spinel structure.6) Also, manganese oxidation number of $\mathrm{Li}_{4} \mathrm{Mn}_{5} \mathrm{O}_{12}$ and $\mathrm{Li}_{2} \mathrm{Mn}_{3} \mathrm{O}_{7}$ is the same as +4 . So, they had been known as no capacity in $4 \mathrm{~V}$ region since manganese is not able to oxidize from +4 to +5 . However, some researchers ${ }^{7,8)}$ reported that $\mathrm{Li}_{4} \mathrm{Mn}_{5} \mathrm{O}_{12}$ showed low capacity in $4 \mathrm{~V}$ region since manganese in $\mathrm{Li}_{4} \mathrm{Mn}_{5} \mathrm{O}_{12}$ was not fully oxidized to +4 . Moreover, our previous study reported that $\mathrm{Li}_{4} \mathrm{Mn}_{5} \mathrm{O}_{12}$ was able to charge-discharge in $4 \mathrm{~V}$ region and $\mathrm{AC} / \mathrm{Li}_{4} \mathrm{Mn}_{5} \mathrm{O}_{12}$ capacitor showed good energy density. ${ }^{4,5)}$ It had been also known that $\mathrm{Li}_{4} \mathrm{Mn}_{5} \mathrm{O}_{12}$ and $\mathrm{Li}_{2} \mathrm{Mn}_{3} \mathrm{O}_{7}$ were synthesized about $400^{\circ} \mathrm{C}$ for $1 \sim$

${ }^{\dagger}$ Corresponding author. Tel.: +82-42-860-3271

E-mail address: csjin@kier.re.kr 3days. ${ }^{6)}$ But, it was reported that $\mathrm{Li}_{4} \mathrm{Mn}_{5} \mathrm{O}_{12}$ synthesized at $400^{\circ} \mathrm{C}$ for a few hours. ${ }^{1)}$ Therefore, we expect that it is possible to synthesize at low temperature for short time as well as $\mathrm{Li}_{2} \mathrm{Mn}_{3} \mathrm{O}_{7}$ is also possible to use cathode material in hybrid capacitor. Hence, hybrid capacitor using $\mathrm{Li}_{2} \mathrm{Mn}_{3} \mathrm{O}_{7}$ has been studied, yet.

In this work, $\mathrm{Li}_{2} \mathrm{Mn}_{3} \mathrm{O}_{7}$ was synthesized by combustion method at the various temperature and time. Deformation of structure was identified by XRD. Morphology of the samples was observed by SEM. Cell performance and cycle ability were investigated in non-aqueous electrolyte system.

\section{Expremental}

$\mathrm{Li}_{2} \mathrm{Mn}_{3} \mathrm{O}_{7}$ was synthesized by combustion method using $\mathrm{LiNO}_{3}, \mathrm{Li}\left(\mathrm{CH}_{3} \mathrm{COO}\right) \cdot 2 \mathrm{H}_{2} \mathrm{O}$ and $\mathrm{Mn}\left(\mathrm{CH}_{3} \mathrm{COO}\right)_{2}$. $4 \mathrm{H}_{2} \mathrm{O}$. The molar ratios of $\mathrm{Li} / \mathrm{Mn}$ and nitrate/acetates were $2: 3$ and $1: 4$, respectively. All materials were dissolved and stirred in deionized water, and then dried at about $80^{\circ} \mathrm{C}$ overnight. The dried mixture was combusted at $300^{\circ} \mathrm{C}$ for $30 \mathrm{~min}$. Combusted material was calcined at various temperature $(350,400,500$, and $\left.600^{\circ} \mathrm{C}\right)$ for various time $(2,5$, and $10 \mathrm{~h})$ in air. 
Synthesized $\mathrm{Li}_{2} \mathrm{Mn}_{3} \mathrm{O}_{7}$ samples were identified by $\mathrm{X}$-ray diffraction (XRD) using $\mathrm{CuK} \alpha$ radiation. In order to observe the morphology of the samples, scanning electron microscopy (SEM) was used.

Electrodes of $\mathrm{Li}_{2} \mathrm{Mn}_{3} \mathrm{O}_{7}$ and $\mathrm{AC}$ were made by the slurry casting method. Slurry mixture of the $\mathrm{Li}_{2} \mathrm{Mn}_{3} \mathrm{O}_{7}$ electrode consisted of the synthesized $\mathrm{Li}_{2} \mathrm{Mn}_{3} \mathrm{O}_{7}$ (85 wt.\%) as active material, super-p (10wt.\%) as conducting material and poly-vinylidene fluoride (PVDF, $5 \mathrm{wt} . \%)$ as binder. Slurry mixture of the carbon electrode consisted of A. C. (activated carbon : MSP $20,85 \mathrm{wt} . \%$ ) as active material, super-p (10 wt.\%) as conducting material and carboxymethyl cellulose (CMC, 3 wt.\%), styrene-butadiene rubber (SBR, $1 \mathrm{wt} . \%)$ and polytetrafluoroethylene (PTFE, $1 \mathrm{wt} . \%$ ) as binder. The slurries were coated on etched Al-foil using Dr. blade and then dried at $80^{\circ} \mathrm{C}$ overnight.

$\mathrm{Li} / \mathrm{Li}_{2} \mathrm{Mn}_{3} \mathrm{O}_{7}$ and $\mathrm{Li} / \mathrm{AC}$ half-cell tests were accomplished by 2032 coin cell. $\mathrm{Li}_{2} \mathrm{Mn}_{3} \mathrm{O}_{7}$ and $\mathrm{AC}$ were used as positive material. Li-foil was used as negative material. $\mathrm{LiPF}_{6}$ in $\mathrm{PC}$ and Celgard 3501 were prepared for electrolyte and separator, respectively.

$\mathrm{AC} / \mathrm{Li}_{2} \mathrm{Mn}_{3} \mathrm{O}_{7}$ full-cell hybrid capacitor test was accomplished by pouch type cell. Electrode area was $3 \times 3 \mathrm{~cm}^{2} . \mathrm{Li}_{2} \mathrm{Mn}_{3} \mathrm{O}_{7}$ and $\mathrm{AC}$ were used as positive and negative material in full-cell, respectively. $\mathrm{LiPF}_{6}$ in PC and Celgard 3501 were prepared for electrolyte and separator, respectively. All cells were fabricated in argon-filled glove box.

Charge-discharge tests of $\mathrm{Li} / \mathrm{Li}_{2} \mathrm{Mn}_{3} \mathrm{O}_{7}$ and $\mathrm{Li} / \mathrm{AC}$ half-cell were performed at various current density in 3.7 4. $4 \mathrm{~V}$ and $2 \sim 3 \mathrm{~V}$, respectively. Applied current of $\mathrm{Li} / \mathrm{Li}_{2} \mathrm{Mn}_{3} \mathrm{O}_{7}$ half-cell was $11,16,30,55,100,150$ and $250 \mathrm{~mA} / \mathrm{g}$. Applied current of Li/AC half-cell was $10,20,50,100,200$ and $400 \mathrm{~mA} / \mathrm{g}$.

Charge-discharge test of $\mathrm{AC} / \mathrm{Li}_{2} \mathrm{Mn}_{3} \mathrm{O}_{7}$ full-cell hybrid capacitor was carried out constant current (CC) - constant voltage (CV) charge and constant current discharge. Each step of charge-discharge test set rest time for 10 second. Applied current was 100, $300,600,900$, and $1200 \mathrm{~mA} / \mathrm{g}$ and operating window was $1 \sim 2.5 \mathrm{~V}$.

\section{Results and Discussion}

Fig. 1 is the X-ray diffraction patterns of $\mathrm{Li}_{2} \mathrm{Mn}_{3} \mathrm{O}_{7}$ calcined at $350,400,500$, and $600^{\circ} \mathrm{C}$ for 2,5 , and $10 \mathrm{~h}$. The samples calcined over $400^{\circ} \mathrm{C}$ showed spinel pattern. But the sample calcined at $350^{\circ} \mathrm{C}$ showed the
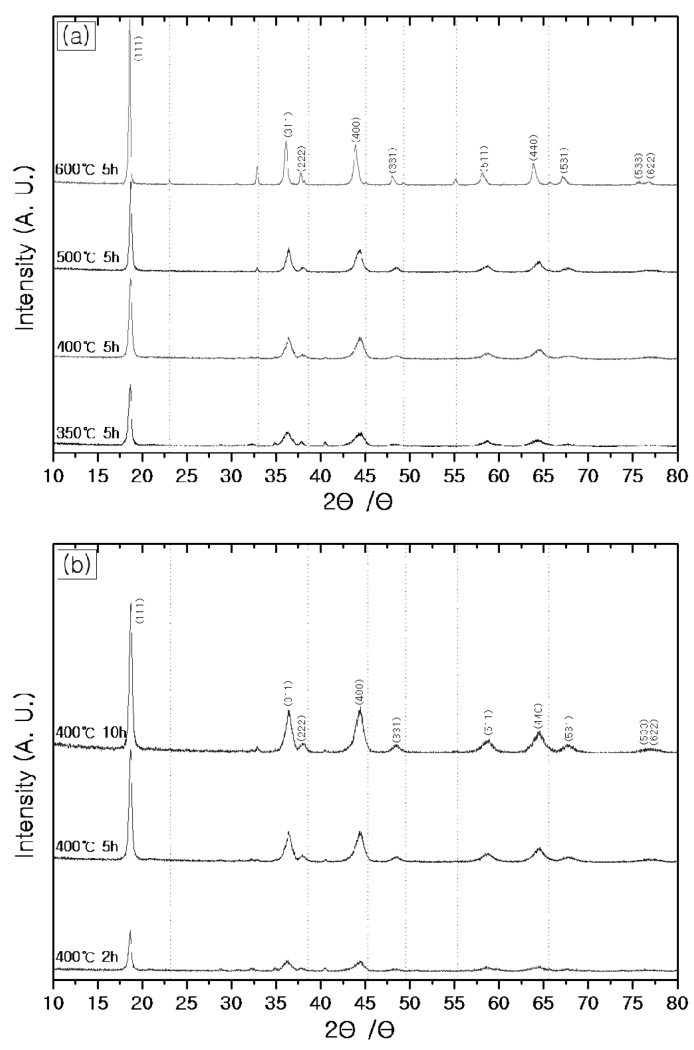

Fig. 1. X-ray diffraction patterns of $\mathrm{Li}_{2} \mathrm{Mn}_{3} \mathrm{O}_{7}$ calcined at (a) $350,400,500$, and $600^{\circ} \mathrm{C}$ for $5 \mathrm{~h}$ and (b) calcined at $400^{\circ} \mathrm{C}$ for 2, 5, and $10 \mathrm{~h}$. (dash lines : $\mathrm{Mn}_{2} \mathrm{O}_{3}$ )

mixture pattern of $\mathrm{Fd} 3 \mathrm{~m}$ and unknown. All peaks were broad which was considered to the low crystallinity resulted in the low calcined temperature and time. As the calcined temperature and time increased, peak intensity increased. Intensity of $\mathrm{Mn}_{2} \mathrm{O}_{3}$ peak also increased as the calcined temperature increased. Some researchers ${ }^{10-12)}$ reported that, due to the manganese reduction from tetravalent to trivalent, $\mathrm{Li}_{4} \mathrm{Mn}_{5} \mathrm{O}_{12}$ suffered decomposition as the calcined temperature increased. Ideal oxidation number of $\mathrm{Li}_{2} \mathrm{Mn}_{3} \mathrm{O}_{7}$ and $\mathrm{Li}_{4} \mathrm{Mn}_{5} \mathrm{O}_{12}$ was +4 . Moreover, $\mathrm{Li}$ and $\mathrm{Mn}$ ion array of $\mathrm{Li}_{2} \mathrm{Mn}_{3} \mathrm{O}_{7}$ and $\mathrm{Li}_{4} \mathrm{Mn}_{5} \mathrm{O}_{12}$ were similar. Therefore, we suggest that $\mathrm{Li}_{2} \mathrm{Mn}_{3} \mathrm{O}_{7}$ suffered decomposition in which manganese reduced from tetravalent to trivalent. Especially, in the case of the sample calcined at $600^{\circ} \mathrm{C}$ for $5 \mathrm{~h}$, it was clearly observed that peaks shifted to low angle. In order to investigate the structural change, lattice constant was calculated and summarized in Fig. 2. In Fig. 2, the sample calcined at $600^{\circ} \mathrm{C}$ for 


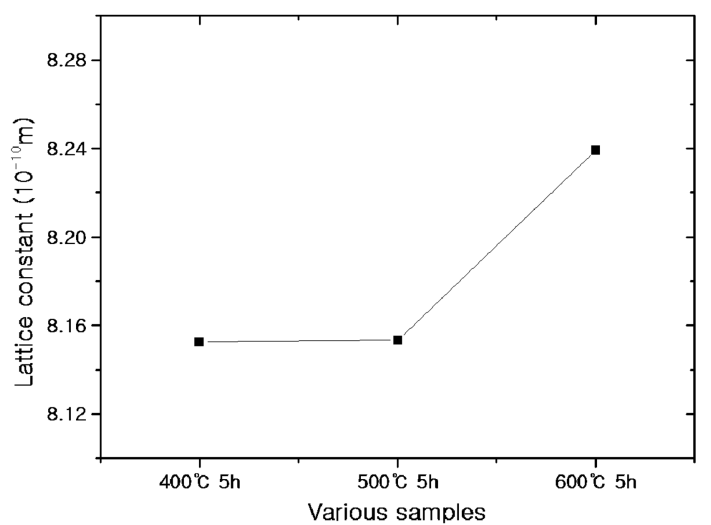

Fig. 2. Lattice constant change of $\mathrm{Li}_{2} \mathrm{Mn}_{3} \mathrm{O}_{7}$ calcined at 400 , 500 , and $600^{\circ} \mathrm{C}$ for $5 \mathrm{~h}$.

$5 \mathrm{~h}$ had higher lattice constant than other calcined samples. Lattice constants of $\mathrm{LiMn}_{2} \mathrm{O}_{4}$ and $\mathrm{Li}_{2} \mathrm{Mn}_{3} \mathrm{O}_{7}$ were $\mathrm{a}=8.247 \AA$ (JCPDS card no. : 35-0782) and $\mathrm{a}=8.160 \AA$ (JCPDS card no. : 83-0321), respectively. Compared to the lattice constant of $\mathrm{LiMn}_{2} \mathrm{O}_{4}$, the lattice constant of the sample calcined at $600^{\circ} \mathrm{C}$ for $5 \mathrm{~h}$ was only similar. The others were similar lattice constant compared to the lattice constant of $\mathrm{LiMn}_{2} \mathrm{O}_{4}$. Therefore, it is considered that molecular formula of $\mathrm{Li}_{2} \mathrm{Mn}_{3} \mathrm{O}_{7}$ calcined at $600^{\circ} \mathrm{C}$ for $5 \mathrm{~h}$ would be changed. In the XRD pattern of $\mathrm{Li}_{2} \mathrm{Mn}_{3} \mathrm{O}_{7}$ calcined at $600^{\circ} \mathrm{C}$ for $5 \mathrm{~h}$, the intergrated intensity ratio between $\mathrm{I}_{(111)}$ of the highest spinel peak and $\mathrm{I}_{(222)}$ of highest $\mathrm{Mn}_{2} \mathrm{O}_{3}$ (about $2 \theta=32.8$ ) peak was about $9: 1$. So, decomposition process of $\mathrm{Li}_{2} \mathrm{Mn}_{3} \mathrm{O}_{7}$ calcined at $600^{\circ} \mathrm{C}$ for $5 \mathrm{~h}$ was considered as below,

$$
7 \mathrm{Li}_{2} \mathrm{Mn}_{3} \mathrm{O}_{7} \rightarrow 9 \mathrm{LiMn}_{2} \mathrm{O}_{4}+\mathrm{Mn}_{2} \mathrm{O}_{3}+5 \mathrm{Li}+5 \mathrm{O}_{2}
$$

Fig. 3 is SEM picture of $\mathrm{Li}_{2} \mathrm{Mn}_{3} \mathrm{O}_{7}$ calcined at 350 , 400 , and $500^{\circ} \mathrm{C}$ for 2,5 , and $10 \mathrm{~h}$. In the case of the sample calcined at $400^{\circ} \mathrm{C}$ for $5 \mathrm{~h}$, particle size was about $1 \mu \mathrm{m}$. It was larger particle size compared to $\mathrm{Li}_{4} \mathrm{Mn}_{5} \mathrm{O}_{12}{ }^{7,8)}$ All samples showing spinel pattern observed a square shape. However, the shape of the sample calcined at $350^{\circ} \mathrm{C}$ for $5 \mathrm{~h}$ looked like sea urchin. It was observed that particles were larger as the calcined temperature and time increased.

Fig. 4 is the rate capability of $\mathrm{Li}_{2} \mathrm{Mn}_{3} \mathrm{O}_{7}$ calcined at 400,500 , and $600^{\circ} \mathrm{C}$ for 2,5 , and $10 \mathrm{~h}$. Discharge capacity of the sample calcined at $500^{\circ} \mathrm{C}$ for $5 \mathrm{~h}$ was higher than other calcined samples at $10 \mathrm{~mA} / \mathrm{g}$. But, at higher current density, discharge capacity of the sample calcined at $500^{\circ} \mathrm{C}$ for $5 \mathrm{~h}$ was lower than of the sample calcined at $400^{\circ} \mathrm{C}$ for $5 \mathrm{~h}$. When the calcined temperature fixed at $400^{\circ} \mathrm{C}$ and the calcined time changed, the sample calcined for $5 \mathrm{~h}$ showed better discharge capacity and rate capability than other calcined samples. So, calcined temperature and time of $\mathrm{Li}_{2} \mathrm{Mn}_{3} \mathrm{O}_{7}$ determined $400^{\circ} \mathrm{C}$ and $5 \mathrm{~h}$, respectively.

Charge-discharge curves at different current density of $\mathrm{Li}_{2} \mathrm{Mn}_{3} \mathrm{O}_{7}$ calcined at $400^{\circ} \mathrm{C}$ for $5 \mathrm{~h}$ were showed in Fig. 5. Compared to $\mathrm{Li}_{4} \mathrm{Mn}_{5} \mathrm{O}_{12}$, the shape of chargedischarge curves was similar. However, these curves were more distinctly observed to two plateau than $\mathrm{Li}_{4} \mathrm{Mn}_{5} \mathrm{O}_{12}$. Discharge capacity of $\mathrm{Li}_{2} \mathrm{Mn}_{3} \mathrm{O}_{7}$ at low current density was higher than $\mathrm{Li}_{4} \mathrm{Mn}_{5} \mathrm{O}_{12} .{ }^{4,5)}$
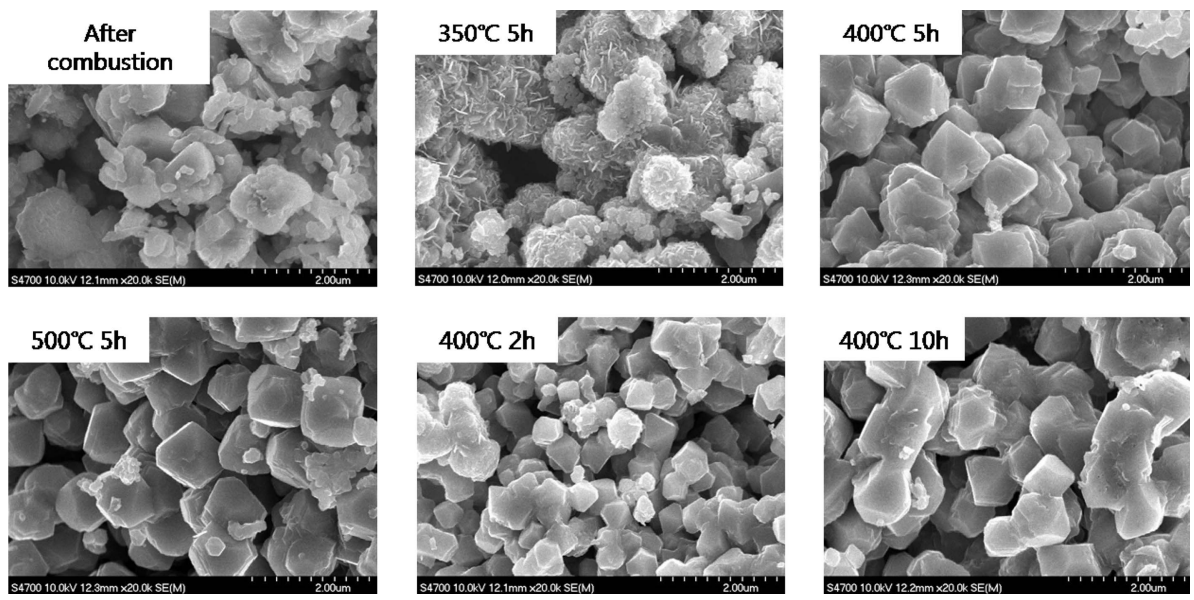

Fig. 3. SEM picture of $\mathrm{Li}_{2} \mathrm{Mn}_{3} \mathrm{O}_{7}$ calcined at various temperature for various time. 

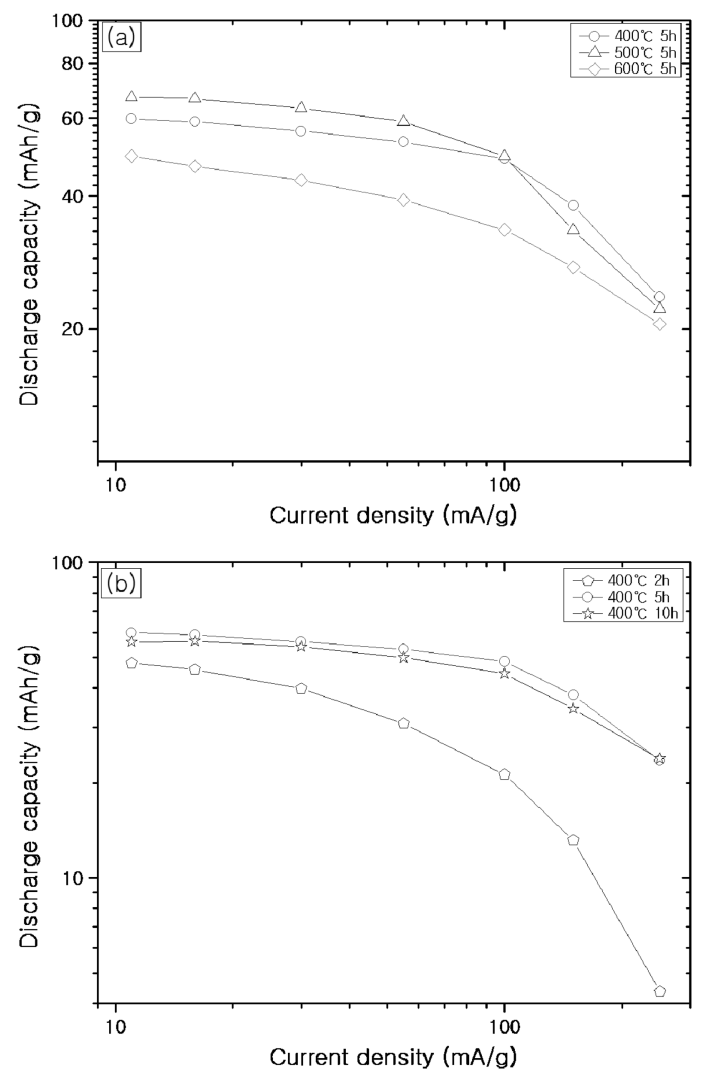

Fig. 4. Rate capability of $\mathrm{Li}_{2} \mathrm{Mn}_{3} \mathrm{O}_{7}$ calcined at (a) 400,500 , and $600^{\circ} \mathrm{C}$ for $5 \mathrm{~h}$ and (b) calcined at $400^{\circ} \mathrm{C}$ for 2,5 , and $10 \mathrm{~h}$.

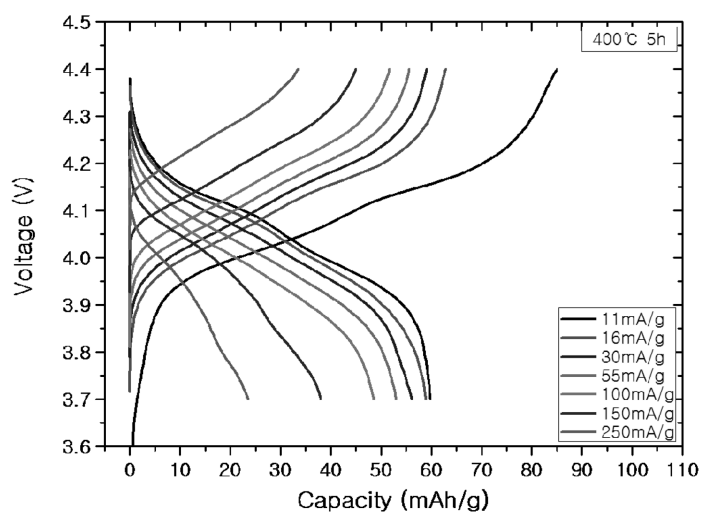

Fig. 5. Charge-discharge curves at different current density of $\mathrm{Li}_{2} \mathrm{Mn}_{3} \mathrm{O}_{7}$ calcined at $400^{\circ} \mathrm{C}$ for $5 \mathrm{~h}$.

Fig. 6 is dQ/dV vs. $\mathrm{V}$ curve of the sample calcined at $400^{\circ} \mathrm{C}$ for $5 \mathrm{~h}$. The peak voltage was observed around 4 and $4.15 \mathrm{~V}$. The values of peak voltage and the shape of the curve resembled $\mathrm{LiMn}_{2} \mathrm{O}_{4}$. Thackeray et al. ${ }^{13)}$ suggested that $\mathrm{Li}_{2} \mathrm{Mn}_{3} \mathrm{O}_{7}$ could be rewrite

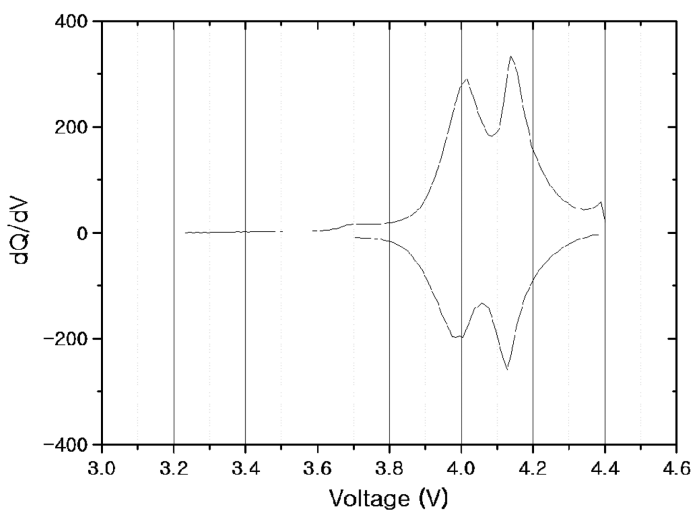

Fig. 6. $d Q / d V$ vs. V curve of the sample calcined at $400^{\circ} \mathrm{C}$ for $5 \mathrm{~h}$.



Fig. 7. Charge-discharge curves at different current density of $\mathrm{AC}$.

to spinel notation like $\mathrm{Li}_{0.85}\left[\mathrm{Mn}_{1.74} \mathrm{Li}_{0.26}\right] \mathrm{O}_{4}$ (or $\mathrm{Li}_{1.11} \mathrm{Mn}_{1.74} \mathrm{O}_{4}$ ). This notation was similar to lithium rich spinel such as $\mathrm{Li}_{1+\mathrm{x}} \mathrm{Mn}_{2-\mathrm{x}} \mathrm{O}_{4}$. So, it is considered when $\mathrm{Li}_{2} \mathrm{Mn}_{3} \mathrm{O}_{7}$ cycled in $4 \mathrm{~V}$ range, values of peak voltage and shape of the curve looked like $\mathrm{LiMn}_{2} \mathrm{O}_{4}$.

In order to decide the $\mathrm{n} / \mathrm{p}$ ratio, half-cell test of $\mathrm{AC}$ carried out, and the result showed in Fig. 7. All curves seemed to be linear shape. In Fig. 5, discharge capacity at $100 \mathrm{~mA} / \mathrm{g}$ was $48.53 \mathrm{mAh} / \mathrm{g}$. And, in Fig. 7, charge capacity at $100 \mathrm{~mA} / \mathrm{g}$ of $\mathrm{AC}$ was $23.28 \mathrm{~mA} / \mathrm{g}$. So, the mass ratio between $\mathrm{Li}_{2} \mathrm{Mn}_{3} \mathrm{O}_{7}$ calcined at $400^{\circ} \mathrm{C}$ for $5 \mathrm{~h}$ and $\mathrm{AC}$ decided to $1: 2.08 . \mathrm{AC} / \mathrm{Li}_{2} \mathrm{Mn}_{3} \mathrm{O}_{7}$ full cell fabricated by the decided mass ratio, and then chargedischarge test performed.

Fig. 8 is discharge curves of $\mathrm{AC} / \mathrm{Li}_{2} \mathrm{Mn}_{3} \mathrm{O}_{7}$ hybrid capacitor at various current density in $1 \sim 2.5 \mathrm{~V}$. Discharge curves showed nearly linear at low current density, although non-linear discharge shape was 


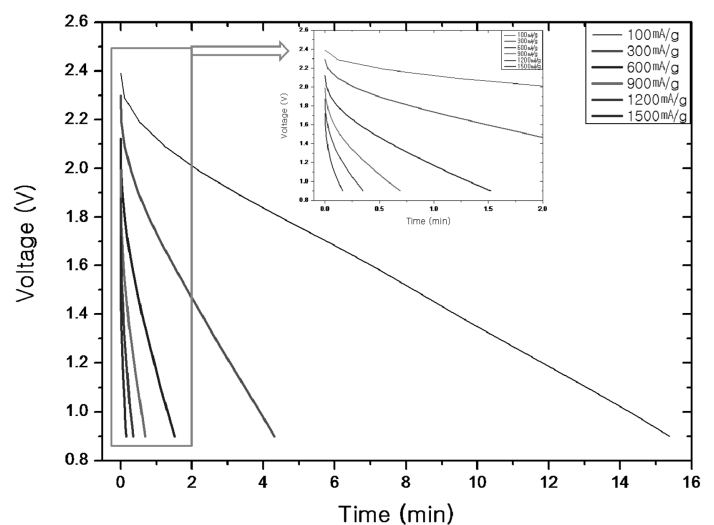

Fig. 8. Discharge curves of $\mathrm{AC} / \mathrm{Li}_{2} \mathrm{Mn}_{3} \mathrm{O}_{7}$ hybrid capacitor at various current density in $1 \sim 2.5 \mathrm{~V}$.

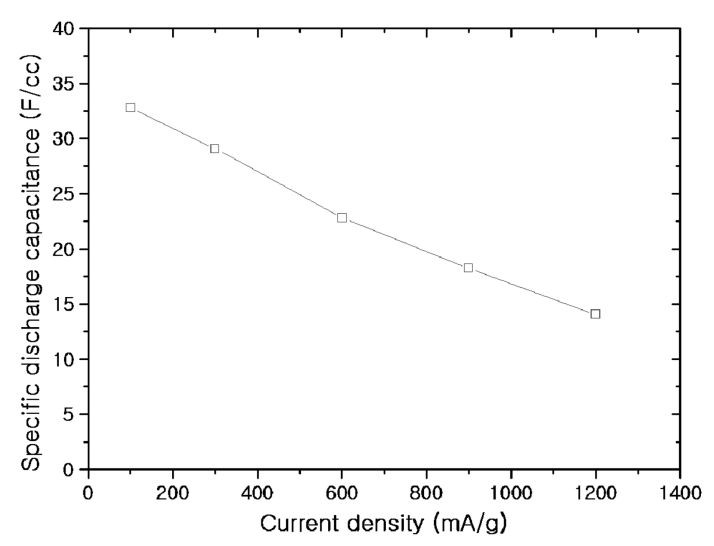

Fig. 9. Rate capability of $\mathrm{AC} / \mathrm{Li}_{2} \mathrm{Mn}_{3} \mathrm{O}_{7}$ hybrid capacitor.

observed at higher current density. By using the data in Fig. 8, volumetric discharge capacitance was calculated, and the result showed in Fig. 9. The equation as below:

$$
C=\frac{\Delta t \times I}{\Delta V \times A}
$$

where $\mathrm{C}$ is volumetric discharge capacitance, $\Delta \mathrm{t}$ is discharge time, $\mathrm{I}$ is applied current, $\Delta \mathrm{V}$ is voltage difference and $\mathrm{A}$ is sum of total electrode volume. $\mathrm{AC} / \mathrm{Li}_{2} \mathrm{Mn}_{3} \mathrm{O}_{7}$ hybrid capacitor had high discharge capacitance of $32.8 \mathrm{~F} / \mathrm{cc}$ at $100 \mathrm{~mA} / \mathrm{g}$ and it had good discharge capacitance of $14.1 \mathrm{~F} / \mathrm{cc}$ at $1200 \mathrm{~mA} / \mathrm{g}$.

\section{Conclusion}

$\mathrm{Li}_{2} \mathrm{Mn}_{3} \mathrm{O}_{7}$ was synthesized by combustion method using $\mathrm{LiNO}_{3}, \mathrm{Li}\left(\mathrm{CH}_{3} \mathrm{COO}\right) \cdot 2 \mathrm{H}_{2} \mathrm{O}$ and $\mathrm{Mn}\left(\mathrm{CH}_{3} \mathrm{COO}\right)_{2}$. $4 \mathrm{H}_{2} \mathrm{O}$. The samples calcined over $400^{\circ} \mathrm{C}$ showed spinel pattern. However, intensity of $\mathrm{Mn}_{2} \mathrm{O}_{3}$ peak increased as the calcined temperature increased. It is considered that $\mathrm{Li}_{2} \mathrm{Mn}_{3} \mathrm{O}_{7}$ suffered decomposition since oxidation number of manganese changed when temperature elevated. Decomposition process of the sample calcined $600^{\circ} \mathrm{C} 5 \mathrm{~h}$ described using direct comparison method. Through the SEM pictures, particle size was about $1 \mu \mathrm{m}$ and it was larger compared to $\mathrm{Li}_{4} \mathrm{Mn}_{5} \mathrm{O}_{12}$. In half-cell test, discharge capacity of the sample calcined at $400^{\circ} \mathrm{C}$ for $5 \mathrm{~h}$ was not only good at $10 \mathrm{~mA} / \mathrm{g}$ but also better rate capability than other calcined sample. In $\mathrm{dQ} / \mathrm{dV} v s$. V curve, values of peak voltage and shape of the curve were similar between $\mathrm{Li}_{2} \mathrm{Mn}_{3} \mathrm{O}_{7}$ and $\mathrm{LiMn}_{2} \mathrm{O}_{4}$. Applying to $\mathrm{AC} / \mathrm{Li}_{2} \mathrm{Mn}_{3} \mathrm{O}_{7}$ hybrid capacitor, discharge curves showed nearly linear at low current density. Volumetric discharge capacitance showed $32.8 \mathrm{~F} / \mathrm{cc}$ at $100 \mathrm{~mA} / \mathrm{g}$ and $14.1 \mathrm{~F} / \mathrm{cc}$ at $1200 \mathrm{~mA} / \mathrm{g}$.

\section{Acknowledgment}

This work was supported by the Ministry of Knowledge Economy, Korea (2010T100100970).

\section{References}

1. Y.J. Hao, Y.Y. Wang, Q.Y. Lai, Y. Zhao, L.M. Chen and X.Y. Ji, J. Solid State Electrochem., 13, 905 (2009).

2. H.Y. Chu, Q.Y. Lai, Y.J. Hao, Y. Zhao and X.Y. Xu, J. Appl. Electrochem., 39, 2207 (2009).

3. Y. Zhao, X.Y. Xu, Q.Y. Lai, Y.J. Hao, L. Wang and Z. Lin, J. Solid State Electrochem., 14, 1509 (2010).

4. H.U. Kim, Y.-K. Sun, K.H. Shin and C.S. Jin, Phys. Scr, T139, 014053 (2010).

5. H.U. Kim, Y.-K. Sun, B.-S. Lee, C.S. Jin and K.Y. Shin, J. Kor. Electrochem. Soc., 13, 103 (2010).

6. M.M. Thackeray, Prog. Solid St. Chem., 25, 1 (1997).

7. Y.J. Shin and A. Manthiram, Electrochim. Acta, 48, 3583 (2003).

8. T. Takada, H. Hayakawa, E. Akiba, F. Izumi and B.C. Chakoumakos, J. Power Sources, 68, 613 (1997).

9. J.P. Zheng, J. Electrochemical Soc., 150, A48 (2003).

10. T. Takada, H. Hayakawa and E. Akiba, J. Solid State Chem., 115, 420 (1995).

11. T. Takada, H. Hayakawa, T. Kumagai and E. Akiba, J. Solid State Chem., 121, 79 (1996).

12. M.M. Thackeray, M.F. Mansuetto and C.S. Johnson, $J$. Solid State Chem., 125, 274 (1996).

13. M.M. Thackeray, A de Kock and W.I.F. David, Mater. Res, Bull., 28, 1041 (1993). 